\title{
Pengaruh Penerapan Model Pembelajaran Kooperatif Tipe Team Assisted Individualization (TAI) terhadap Kemampuan Pemahaman Konsep Matematis ditinjau dari Pengetahuan Awal Matematika Siswa Madrasah Tsanawiyah
}

\author{
Uzli Fatil Jannah ${ }^{1}$, Depi Fitraini², Irma Fitri ${ }^{3}$ \\ 1,2,3 Program studi pendidikan matematika, Universitas Islam Negeri Sultan Syarif Kasim Riau \\ e-mail: depi.fitraini@,uin-suska.ac.id,irma.fitri@,uin-suska.ac.id
}

\begin{abstract}
ABSTRAK. Penelitian ini merupakan penelitian eksperimen dengan jenis penelitian Quasi Eksperimen dan bertujuan untuk mengetahui pengaruh penerapan model pembelajaran kooperatif tipe Team Assisted Individualization (TAI) terhadap kemampuan pemahaman konsep matematis ditinjau dari pengetahuan awal matematika siswa Madrasah Tsanawiyah. Populasi dalam penelitian ini adalah seluruh siswa kelas VIII MTs Al-Munawwarah Pekanbaru tahun pelajaran 2018/2019 yang berjumlah 109 siswa dan sampel dalam penelitian ini adalah kelas VIII. Fatimah sebagai kelas eksperimen dan kelas VIII. Aisyah sebagai kelas kontrol. Pengambilan sampel dilakukan dengan teknik purposive sampling. Teknik analisis data menggunakan uji $\mathrm{t}$ dan uji anova dua arah. Berdasarkan hasil analisis data dapat diambil kesimpulan bahwa: 1) Terdapat perbedaan kemampuan pemahaman konsep matematis yang belajar menggunakan model pembelajaran kooperatif tipe Team Assisted Individualization (TAI) dengan siswa yang belajar menggunakan model pembelajaran langsung. 2) Terdapat perbedaan kemampuan pemahaman konsep matematis antara siswa dengan pengetahuan awal matematika tinggi, sedang dan rendah. 3) Tidak terdapat pengaruh interaksi antara model pembelajaran kooperatif tipe Team Assisted Individualization (TAI) ditinjau dari pengetahuan awal terhadap pemahaman konsep matematis.
\end{abstract}

Kata kunci:Model Pembelajaran Kooperatif Tipe Team Assisted Individualization (TAI), Kemampuan Pemahaman Konsep Matematis, Pengetahuan Awal Matematika Siswa.

\section{PENDAHULUAN}

Matematika mempunyai peranan penting dalam kehidupan manusia, seperti dalam pendidikan formal dari sekolah dasar sampai perguruan tinggi, matematika menjadi salah satu pelajaran wajib. Disadari ataupun tidak disadari, konsep matematika banyak digunakan dalam kegiatan sehari-hari.Setiap manusia dalam kegiatan hidupnya akan terlibat dengan matematika, mulai dari bentuk yang sederhana dan rutin sampai pada produk. Misalnya, menghitung dan membilang, dua contoh kegiatan matematika rutin dan sederhana, hampir dikerjakan oleh setiap orang (Heris Hendriana \& Utari Soemarmo, 2014). Berubahnya pandangan dalam pembelajaran matematika dari mengahafal ke memahami telah merubah pandangan mengenai bagaimana matematika itu seharusnya di ajarkan.

Pembelajaran matematika di sekolah yang biasanya tertumpu pada latihan berhitung dan menghafal sekarang pembelajaran matematika lebih menekankan pada pemahaman konsep dasar dan pemecahan masalah. Dengan adanya pemahaman dalam pembelajaran matematika, akan mengurangi kesulitan dalam mengikuti pembelajaran matematika, juga dalam menyelesaikan persoalan-persoalan kontekstual yang sering dijumpai dalam kehidupan sehari-hari.

Pembelajaran matematika yang dirumuskan oleh National Council of Teachers of Mathematics atau NCTM mengariskan, bahwa siswa harus mempelajari matematika melalui pemahaman dan aktif membangun pengetahuan baru dari pengalaman dan pengetahuan yang dimiliki sebelumnya 
( Risnawati, 2013). Diungkap dalam Garis-garis Besar Program Pengajaran (GBPP) matematika, bahwa tujuan umum diberikannya matematika pada jenjang pendidikan dasar dan menengah meliputi dua hal yaitu:

1. Mempersiapkan siswa agar sanggup dalam menghadapi perubahan keadaan di dalam kehidupan dan di dunia yang selalu berkembang, melalui latihan bertindak atas dasar pemikiran secara logis, rasional, kritis, kreatif, cermat, jujur, efektif dan efisien.

2. Mempersiapkan siswa agar dapat menggunakan matematika dan pola pikir matematika dalam kehidupan sehari-hari, dan dalam mempelajari berbagai ilmu pengetahuan (Tim MKPBM Jurusan Pendidikan Matematika'2001).

Agar tercapai tujuan pembelajaran matematika di sekolah, guru perlu membuat model pembelajaran matematika yang menyenangkan bagi siswa, dan setiap siswa dapat memahami materi yang dipelajari. Pemahaman konsep matematis siswa sangat penting agar siswa dapat mengikuti pembelajaran matematika.

Pemahaman merupakan kemampuan untuk menangkap arti materi pelajaran yang dapat berupa kata, angka, menjelaskan sebab akibat (Mas'ud Zein \& Darto' 2017). Kemampuan pemahaman konsep matematis adalah kemampuan yang menyerap dan memahami ide-ide matematika yang menyeluruh dan fungsional (Karunia Eka Lestari \& Mokhammad Ridwan Yudhanegara 2017).

Berdasarkan hasil wawancara dengan salah seorang guru matematika di MTs AlMunawwarah Tangkerang Timur-Pekanbaru, diperoleh informasi bahwa kemampuan pemahaman konsep siswa masih tergolong rendah dan dalam proses pembelajaran secara umum menerapkan pembelajaran langsung. Selain wawancara, peneliti juga memberikan tes berupa soal uraian untuk mengukur kemampuan pemahaman konsep matematis siswa.

Berikut adalah salah satu jawaban siswa:

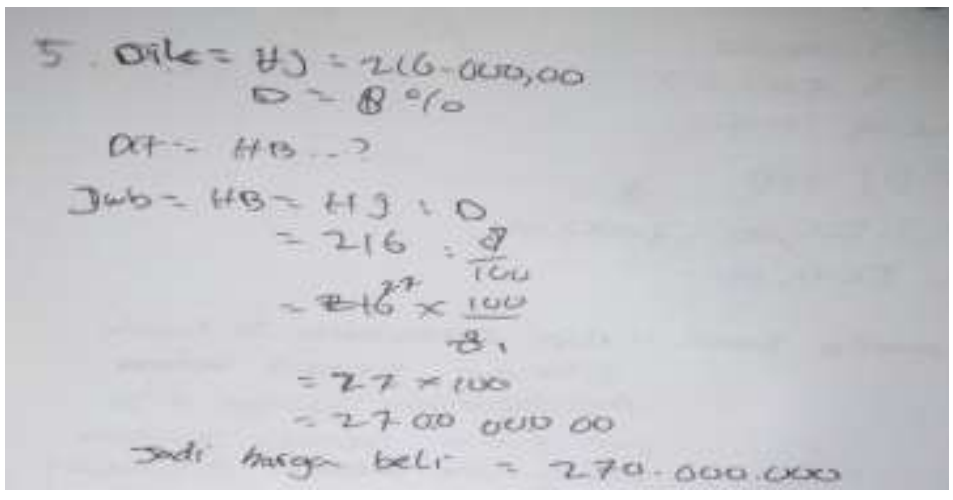

Gambar 1. Salah satu jawaban siswa

Hasil tes tersebut juga membuktikan bahwa kemampuan pemahaman konsep matematis siswa masih rendah, yang terlihat dari $86,67 \%$ siswa kesulitan untuk menyatakan ulang sebuah konsep, 30,83\% siswa kesulitan untuk mengklasifikasikan objek menurut sifat-sifat tertentu sesuai dengan konsepnya dan mengaplikasikan konsep atau algoritma pada pemecahan masalah, 54,17\% siswa kesulitan memberikan contoh dan bukan contoh dari suatu konsep, 57,26\% siswa kesulitan menyajikan konsep dalam berbagai bentuk representasi matematis, 83,33\% siswa kesulitan mengembangkan syarat perlu atau syarat cukup dari suatu konsep, 38,33\% siswa kesulitan menggunakan dan memanfaatkan serta memilih prosedur atau operasi tertentu.

Berdasarkan hal tersebut diperlukan model pembelajaran yang dapat meningkatkan kemampuan pemahaman konsep matematis siswa, salah satunya yaitu dengan membentuk kelompok. Jadi pembelajaran kelompok, diharapkan setiap anggota dalam kelompok dapat 
memahami materi yang di berikan, dengan memberikan tanggung jawab terhadap masing-masing anggota kelompok untuk memahami materi, sehingga setiap siswa terlibat aktif dalam kelompok.

Model pembelajaran yang dapat diterapkan oleh guru adalah model pembelajaran kooperatif yang merupakan model pembelajaran kelompok yang memiliki aturan-aturan tertentu. Prinsip dasar pembelajaran kooperatif adalah siswa membentuk kelompok kecil dan saling mengajar sesamanya untuk mencapai tujuan bersama (Made Wena'2011). Model pembelajaran kelompok yang dapat meninggkatkan kemampuan pemahaman konsep matematis siswa adalah model pembelajaran kooperatif, salah satu tipe model pembelajaran kooperatif yaitu tipe Team Assisted Individualization (TAI).

Berdasarkan hasil penelitian yang dilakukan oleh Imra Atul Husna, Rahmi, dan Rina Febriana diperoleh bahwa model pembelajaran kooperatif tipe TAI dapat meningkatkan aktivitas siswa, pemahaman konsep matematis siswa dengan menerapkan model kooperatif tipe TAI lebih baik daripada pemahaman konsep matematis siswa dengan menerapkan model konvensional (Imra Atul Husna, Rahmi \& Rina Febriana, 2014).Selain itu, hasil penelitian yang dilakukan oleh Sari Desiana Putri, Irawan dan Mukhni menyatakan bahwa pemahaman konsep matematis siswa dengan menerapkan pembelajaran kooperatif tipe TAI lebih baik daripada pemahaman konsep matematis siswa dengan menerapkan pembelajaran konvesional (Sari Desiana Putri, Irawan \& Mukhni, 2014).

Berdasarkan hasil dari beberapa penelitian tersebut, dapat diketahui bahwa model pembelajaran kooperatif tipe TAI dapat meningkatkan kemampuan pemahaman konsep matematis siswa. Model pembelajaran kooperatif tipe TAI merupakan model pembelajaran yang diperkenalkan oleh Slavin dalam Istarani dan Muhammad Ridwan, yang menggabungkan antara model pembelajaran individual dengan model pembelajaran kooperatif dengan pemberian bantuan secara individual (Istarani \& Muhammad Ridwan'2014).

Didalam pembelajaran kooperatif tipe TAI, siswa mempelajari tugas-tugas secara kooperatif dalam kelompoknya. Pekerjaan tiap anggota kelompok diperiksa kemudian diberikan penjelasan oleh yang dipandang lebih menguasai tugas yang bersangkutan, bila ada kesulitan yang tidak dapat diselesaikan oleh teman sekelompok, maka kelompok tersebut dapat meminta bantuan guru (Utari Sumarmo' 2013). Dalam menerapkan model pembelajaran, pengetahuan awal siswa juga digunakan untuk memberi gambaran mengenai kemampuan siswa dalam menguasai materi prasyarat sebelum penelitian dilakukan atau sebelum perlakuan diberikan (Karunia Eka Lestari \& Mokhammad Ridwan Yudhanegara' 2017).

Sehubungan dengan uraian sebelumnya, maka peniliti tertarik untuk melakukan penelitian eksperimen dengan judul Pengaruh Penerapan Model Pembelajaran Kooperatif Tipe Team Assisted Individualization (TAI) Terhadap Kemampuan Pemahaman Konsep Matematis Ditinjau dari Pengetahuan Awal Matematika Siswa Madrasah Tsanawiyah.

\section{METODE}

Penelitian ini dilaksanakan di MTs Al-Munawwarah Pekanbaru siswa kelas VIII semester ganjil tahun ajaran 2018/2019, pada tanggal 18 Juli 2018 sampai dengan 11 Agustus 2018. Populasi dalam penelitian ini adalah siswa kelas VIII MTs Al-Munawwarah Pekanbaru yang terdiri dari 4 kelas dengan jumlah siswa sebanyak 109 orang siswa.

Pemilihan sampel berdasarkan Purposive Sampling yang mempertimbangkan saran dari guru matematika yang menyatakan kelas VIII. Fatimah yang terdiri dari 30 siswa dengan kelas VIII.Aisyah yang terdiri dari 30 siswa adalah homogen. Namun untuk membuktikan homogenitas kelas maka peneliti melakukan uji homogenitas dari hasil uji tes pengetahuan awal matematika di kedua kelas tersebut. Hasil dari uji homogenitas Pengetahuan Awal Matematika (PAM) siswa, terbukti kelas tersebut homogen yang dijelaskan pada lampiran. Adapun untuk melihat kesamaan 
rata-ratanya peneliti melakukan uji t yang menyimpulkan bahwa terdapat kesamaan rata-rata antara kedua kelas sebagaimana perhitungan yang ditunjukan pada lampiran. Dengan demikian peneliti dapat melanjutkan penelitian dikelas tersebut.

Jenis penelitian ini adalah quasi-eksperimen menggunakan nonequivalent posttest-only control group design. Penelitian ini melibatkan dua kelompok sampel yaitu kelompok eksperimen yang memperoleh model pembelajaran kooperatif tipe Team Assited Individualization (TAI) dan kelompok kontrol yang memperoleh model pembelajaran langsung.

\section{HASIL DAN PEMBAHASAN}

\section{Hasil}

Selama pelaksanaan penelitian yang dilakukan sebanyak 5 kali pertemuan untuk pemberian materi menggunakan model Pembelajaran Kooperatif tipe Team Assisted Individualization (TAI)tidak terlepas dari pengamatan dan pantauan guru mata pelajaran matematika yang bertanggung jawab di kelas. Adapun penilaian pengamatan ini dilihat berdasarkan lembar aktivitas guru dan siswa yang telah peneliti siapkan sebelumnya. Hasil aktivitas peneliti dapat dilihat pada tabel berikut:

Tabel 1. Analisis Aktivitas Guru

\begin{tabular}{|c|c|c|c|c|c|c|}
\hline \multirow[t]{2}{*}{ No } & \multirow{2}{*}{ Jenis Aktivitas Guru } & \multicolumn{5}{|c|}{ Pertemuan } \\
\hline & & 1 & 2 & 3 & 4 & 5 \\
\hline 1 & $\begin{array}{l}\text { Guru membentuk kelompok } \\
\text { beranggotakan } 5 \text { orang dan } \\
\text { memberikan lembar kerja siswa } \\
\text { kepada masing-masing kelompok }\end{array}$ & 3 & 3 & 4 & 4 & 4 \\
\hline 2 & $\begin{array}{l}\text { Guru mengontrol dan mengawasi } \\
\text { kelompok }\end{array}$ & 3 & 3 & 4 & 4 & 4 \\
\hline 3 & $\begin{array}{l}\text { Guru meminta siswa untuk } \\
\text { mempresentasikan hasil diskusi }\end{array}$ & 3 & 4 & 4 & 4 & 4 \\
\hline 4 & $\begin{array}{l}\text { Guru memberikan nilai (skor) } \\
\text { pada masing-masing kelompok }\end{array}$ & 4 & 4 & 4 & 4 & 4 \\
\hline 5 & $\begin{array}{l}\text { Guru mempertegas temuan- } \\
\text { temuan hasil diskusi kelompok } \\
\text { dengan menerangkan ulang materi- } \\
\text { materi yang tidak ditemukan siswa } \\
\text { tiap kelompok }\end{array}$ & 3 & 3 & 3 & 3 & 4 \\
\hline 6 & $\begin{array}{l}\text { Guru memberikan soal tes kepada } \\
\text { siswa }\end{array}$ & 3 & 3 & 4 & 4 & 4 \\
\hline & Jumlah & 19 & 20 & 23 & 23 & 24 \\
\hline & Nilai & 79,2 & 83,3 & 95,8 & 95,8 & 100 \\
\hline & Rata-rata & & & & & \\
\hline
\end{tabular}

Berdasarkan tabel tersebut, aktivitas peneliti dalam melaksanakan model pembelajaran kooperatif tipe Team Assisted Individualization (TAI)dapat dikategorikan dengan pelaksanaan yang baik. Untuk pertemuan pertama diperoleh nilai sebesar 79,2 dan tergolong dalam kategori sangat baik. Namun, pada pertemuan pertama ini masih banyak kekurangan dalam pelaksanaan nya, dikarenakan masih ada penyesuaian dan pembiasaan bagi peneliti untuk dapat berinteraksi dengan baik pada setiap siswa.Untuk pertemuan kedua diperoleh nilai 83,3 dan masih dalam kategori 
sangat baik. Hal tersebut menunjukkan bahwa pelaksanaan model pembelajaran telah dapat dilaksanakan dengan baik dibanding pertemuan pertama. Pada pertemuan ketiga sudah memperoleh nilai 95,8, yang juga mengalami peningkatan dari pertemuan sebelumnya, begitu juga dengan pertemuan keempat memperoleh nilai 95,8 dan pada pertemuan kelima memperoleh nilai 100. Menganalisa dari setiap pertemuan yaitu masih terdapat kekurangan dalam pelaksanaan tahapan model pembelajaran disebabkan karena setiap pertemuan memberikan materi baru dan konsep yang baru kepada siswa. Sehingga pelaksanaan pembelajaran memerlukan waktu dan pemahaman yang dalam agar dapat tersampaikan dengan baik.

Rata-rata yang diperoleh oleh peneliti dari awal pertemuan hingga akhir pertemuan sudah tergolong dalam kategori sangat baik dengan nilai 90,82. Selanjutnya akan dibahas mengenai aktivitas siswa yang dilakukan di dalam kelas saat menggunakan model pembelajaran kooperatif tipe Team Asissted Individualization (TAI).

Tabel 2. Analisis Aktivitas Siswa

\begin{tabular}{|c|c|c|c|c|c|c|}
\hline \multirow[t]{2}{*}{$\overline{\text { No }}$} & \multirow[t]{2}{*}{ Jenis Aktivitas Siswa } & \multirow[b]{2}{*}{1} & \multicolumn{4}{|c|}{ Pertemuan } \\
\hline & & & 2 & 3 & 4 & 5 \\
\hline 1 & $\begin{array}{l}\text { Siswa duduk sesuai dengan } \\
\text { kelompok yang telah ditentukan } \\
\text { guru dan menerima lembar kerja } \\
\text { siswa kemudian mencermatinya }\end{array}$ & 3 & 3 & 4 & 4 & 4 \\
\hline 2 & Siswa berdiskusi dalam kelompok & 2 & 3 & 4 & 4 & 4 \\
\hline 3 & $\begin{array}{l}\text { Siwa mempresentasikan hasil } \\
\text { diskusi kelompoknya }\end{array}$ & 3 & 3 & 3 & 3 & 4 \\
\hline 4 & $\begin{array}{l}\text { Siswa mendengarkan dengan } \\
\text { seksama nilai yang diperoleh hasil } \\
\text { kerja kelompok, dan menerima } \\
\text { penghargaan }\end{array}$ & 3 & 4 & 3 & 4 & 4 \\
\hline 5 & $\begin{array}{l}\text { Siswa membandingkan hasil kerja } \\
\text { kelompok dengan materi ajar yang } \\
\text { diterangkan guru }\end{array}$ & 4 & 3 & 3 & 3 & 4 \\
\hline 6 & $\begin{array}{l}\text { Siswa mengerjakan soal yang } \\
\text { diberikan guru pada masing-masing } \\
\text { siswa secara individu }\end{array}$ & 3 & 4 & 3 & 3 & 4 \\
\hline & Jumlah & 18 & 20 & 20 & 21 & 24 \\
\hline & Nilai & 75 & 83,3 & 83,3 & 87,5 & 100 \\
\hline & Rata-rata & & & 85 & & \\
\hline
\end{tabular}

Berdasarkan tabel, maka dapat diperoleh bahwa aktivitas siswa hampir pada setiap pertemuan mengalami peningkatan. Untuk pertemuan pertama diperoleh nilai 75 . Pada pertemuan pertama ini masih banyak kekurangan dari setiap pelaksanaannya. Hal ini disebabkan penggunaan model pembelajaran kooperatif tipe TAI inibelum pernah mereka lakukan, terlebih model ini menutut mereka untuk berdiskusi, sedangkan pelaksanaan pembelajaran yang mereka dapati sebelumnya. Oleh karena itu, untuk pertemuan pertamanya masih memerlukan interaksi, penyesuaian dan pembiasaan bagi siswa. Pertemuan kedua sudah mengalami peningkatan dengan perolehan nilai 83,3 begitu juga dengan pertemuan ketiga. Pada pertemuan keempat penilaian aktivitas siswa memperoleh nilai 87,5 , karena siswa sudah mampu mengikuti pembelajaran dengan baik dan sistematis. Pertemuan kelima siswa sudah sangat baik dalam mengikuti pembelajaran dan aktivitas siswa. Siswa sudah terbiasa untuk melakukan model pembelajaran ini dari awal hingga akhir pembelajaran, siswa mengikutinya dengan baik dan teratur sehingga penilaian aktivitas siswa pada pertemuan terakhir ini mencapai 100. 
Berdasarkan rekapitulasi aktivitas guru dapat diketahui rata-rata pelaksanaan model pembelajaran kooperatif tipe Team Assisted Individualization mencapai 90,82 sedangkan rata - rata aktivitas siswa dalam pembelajaran mencapai 85,82 . Hal ini menunjukkan bahwa guru sebagai peneliti dan siswa telah mampu melaksanakan model pembelajaran kooperatif tipe Team Assisted Individualization.

Peneliti telah dapat melaksanakan setiap langkah-langkah dari model pembelajaran kooperatif tipe Team Assisted Individualization. Pada tahap menyiapkan siswa, menyampaiakan tujuan pembelajaran telah dapat melaksanakannya dengan baik.

Pada tahap membagi siswa kedalam kelompok belajar berdasarkan hasil tes pengetahuan awal peneliti telah dapat melaksanakannya dengan baik dari awal pertemuan hingga akhir pertemuan. Pada awalnya banyak siswa yang belum bisa menerima kelompok yang telah ditentukan namun setelah diberi penjelasan siswa tersebut mau duduk di kelompok yang telah ditentukan kemudian peneliti memberikan LKS kepada masing-masing kelompok, siswa tersebut langsung mencermati LKS dan peneliti mengontrol dan mengawasi proses pembelajaran. Proses pembelajaran dengan model pembelajaran kooperatif tipe Team Assisted Individualization (TAI) pada pertemuan pertemuan pertama namun pada saat presentasi masih terbilang sungkan, untuk itu peneliti memberikan motivasi kepada siswa agar siswa tersebut dapat mengeksplor dirinya. Siswa sangat antusias mendengarkan skor yang diperoleh, dan skor tersebut menjadi sebuah semangat bagi masing-masing kelompok untuk menungkatkan skornya. Meskipun, pada pertemuan pertama, siswa tidak banyak berdiskusi dengan teman sekelompok melainkan cendrung menyelesaikan sendiri dan bertanya dengan gurunya langsung.

Pada pertemuan kedua lebih baik dari pertemuan sebelumnya, siswa sudah lebih menerima kelompoknya dan meskipun belum aktif berdiskusi, dan saat presentasi siswa dari masing-masing kelompok masih ada yang enggan untuk maju ke depan kelas, peneliti memberikan motivasi kepada siswa dari masing-masing kelompok agar dapat mempresentasikan ke depan kelas.

Tahapan meminta siswa untuk mempresentasikan hasil diskusi mulai terlaksana dengan baik pada pertemuan ketiga, di awal-awal pertemuan sebagian besar siswa masih enggan untukberdiskusi, siswa PAM nya tinggi dan PAM sedang cendrung mengerjakan sendiri dan yang PAM nya rendah cendrung diam saja apabila tidak faham namun ada yang bertanya langsung kepada guru sebagai peneliti tanpa menanyakannya terlebih dahulu kepada teman sekelompok. Namun, peneliti meminta kepada setiap kelompok agar dapat terlibat aktif dalam kelompoknya dengan membantu teman dalam kelompoknya untuk memahami materi yang telah di sediakan.

Aktivitas guru dan siswa dalam model pembelajaran kooperatif tipe TAI saling mempengaruhi sattu sama lain. Hal ini dapat dilihat dari rata-rata kegiatan pada pertemuan pertama. Pada penerapan model pembelajaran TAI peneliti mengalami peningkatan pada hampir setiap petemuannya, begitu juga pada aktivitas siswa selama proses pembelajaran.

Pada analisis hipotesis pertama, data yang peneliti dapati adalah data normal dan homogen. Sehingga pengujian hipotesis pertama ini menggunakan Uji t. Uji yang dilakukan dengan kriteria jika nilai signifikan yang diperoleh lebih kecil dari 0,05 maka $\mathrm{H}_{\mathrm{a}}$ diterima, jika nilai signifikan yang diperoleh lebih besar dari 0,05 maka $\mathrm{H}_{0}$ diterima. Hasil pengujian dapat dilihat pada tabel berikut::

Tabel 3. Hasil uji t tes akhir

\begin{tabular}{ccc}
\hline $\boldsymbol{t}_{\text {hitung }}$ & $\boldsymbol{t}_{\text {tabel }} \mathbf{5} \%$ & Keterangan \\
\hline 2,148 & 2,00172 & $H_{a}$ diterima \\
\hline
\end{tabular}

$d k=N_{x}+N_{y}-2=30+30-2=58$ 
Konsultasi pada tabel nilai " $t$ " dengan $d k=58$ dengan taraf signifikan 5\% diperoleh $t_{\text {tabel }}$ sebesar 2,00172 dan $t_{\text {hitung }}$ sebesar 2,148 maka $t_{\text {hitung }} \geq t_{\text {tabel }}$, sehingga $H_{o}$ ditolak dan $\mathrm{H}_{\mathrm{a}}$ diterima. Dengan demikian dapat disimpulkan bahwa terdapat perbedaan kemampuan pemahaman konsep matematis antara siswa yang mengikuti model pembelajaran kooperatif tipe TAI dan siswa yang mengikuti pembelajaran langsung.

Untuk melakukan uji perbedaan pada hipotesis 2 dan 3 maka digunakan uji ANOVA dua arah, yang mana uji ini dilakukan untuk melihat secara langsung perbedaan yang terjadi dalam 3 variabel sekaligus. Adapun hasil dari perhitungan uji anova dua arah ini dapat dilihat pada lampiran. Sedangkan, kesimpulan uji anova dua arah dapat dilihat dari tabel berikut.

Tabel 4. Hasil uji Anova

\begin{tabular}{cccccc}
\hline Sumber Variansi & Dk & JK & RK & Fh & Fk \\
\hline Antar baris (A) & 1 & 2666,7 & 2666,7 & 5,0054 & 4,02 \\
Antar kolom (B) & 2 & 4113,3 & 2056,6 & 3,8604 & 3,17 \\
Interaksi (A*B) & 2 & 627,71 & 313,85 & 0,5891 & 3,17 \\
Dalam & 54 & 28769 & 532,76 & & \\
Total & 59 & 7407,71 & - & & \\
\hline
\end{tabular}

Berdasarkan tabel 2. dapat disimpulkan sebagai berikut:

a. Untuk kolom (antar tingkat Pengetahuan Awal Matematika), harga $F_{\text {hitung }}>F_{\text {tabel }}$, yaitu $5,0054>4,02$. Untuk baris (antara kedua kelas eksperimen dan kelas kontrol), harga $F_{\text {hitung }}>F_{\text {tabel }}$, yaitu $3,8604>3,17$. Hal ini berarti terdapat perbedaan kemampuan pemahaman konsep matematis antara siswa dengan pengetahuan awal matematika tinggi, sedang dan rendah.

b. Untuk interaksi harga $F_{\text {hitung }}<F_{\text {tabel }}$, yaitu $0,589<3,17$. Dengan demikian $H_{a}$ ditolak dan $H_{o}$ diterima. Hal ini berarti tidak terdapat interaksi penerapan model pembelajaran kooperatif tipe TAI dengan pengetahuan awal matematika terhadap kemampuan pemahaman konsep matematis siswa.

\section{Pembahasan}

Berdasarkan rekapitulasi aktivitas guru dapat diketahui rata-rata pelaksanaan model pembelajaran kooperatif tipe Team Assisted Individualization mencapai 90,82 sedangkan rata - rata aktivitas siswa dalam pembelajaran mencapai 85,82 . Hal ini menunjukkan bahwa guru sebagai peneliti dan siswa telah mampu melaksanakan model pembelajaran kooperatif tipe Team Assisted Individualization.

Peneliti telah dapat melaksanakan setiap langkah-langkah dari model pembelajaran kooperatif tipe Team Assisted Individualization. Pada tahap menyiapkan siswa, menyampaiakan tujuan pembelajaran telah dapat melaksanakannya dengan baik.

Pada tahap membagi siswa kedalam kelompok belajar berdasarkan hasil tes pengetahuan awal peneliti telah dapat melaksanakannya dengan baik dari awal pertemuan hingga akhir pertemuan. Pada awalnya banyak siswa yang belum bisa menerima kelompok yang telah ditentukan namun setelah diberi penjelasan siswa tersebut mau duduk di kelompok yang telah ditentukan kemudian peneliti memberikan LKS kepada masing-masing kelompok, siswa tersebut langsung mencermati LKS dan peneliti mengontrol dan mengawasi proses pembelajaran. Proses pembelajaran dengan model pembelajaran kooperatif tipe Team Assisted Individualization (TAI) pada pertemuan pertemuan pertama namun pada saat presentasi masih terbilang sungkan, untuk itu peneliti memberikan motivasi kepada siswa agar siswa tersebut dapat mengeksplor dirinya. Siswa sangat antusias mendengarkan skor yang diperoleh, dan skor tersebut menjadi sebuah 
semangat bagi masing-masing kelompok untuk menungkatkan skornya. Meskipun, pada pertemuan pertama, siswa tidak banyak berdiskusi dengan teman sekelompok melainkan cendrung menyelesaikan sendiri dan bertanya dengan gurunya langsung.

Pada pertemuan kedua lebih baik dari pertemuan sebelumnya, siswa sudah lebih menerima kelompoknya dan meskipun belum aktif berdiskusi, dan saat presentasi siswa dari masing-masing kelompok masih ada yang enggan untuk maju ke depan kelas, peneliti memberikan motivasi kepada siswa dari masing-masing kelompok agar dapat mempresentasikan ke depan kelas.

Tahapan meminta siswa untuk mempresentasikan hasil diskusi mulai terlaksana dengan baik pada pertemuan ketiga, di awal-awal pertemuan sebagian besar siswa masih enggan untukberdiskusi, siswa PAM nya tinggi dan PAM sedang cendrung mengerjakan sendiri dan yang PAM nya rendah cendrung diam saja apabila tidak faham namun ada yang bertanya langsung kepada guru sebagai peneliti tanpa menanyakannya terlebih dahulu kepada teman sekelompok. Namun, peneliti meminta kepada setiap kelompok agar dapat terlibat aktif dalam kelompoknya dengan membantu teman dalam kelompoknya untuk memahami materi yang telah di sediakan.

Aktivitas guru dan siswa dalam model pembelajaran kooperatif tipe TAI saling mempengaruhi sattu sama lain. Hal ini dapat dilihat dari rata-rata kegiatan pada pertemuan pertama. Pada penerapan model pembelajaran TAI peneliti mengalami peningkatan pada hampir setiap petemuannya, begitu juga pada aktivitas siswa selama proses pembelajaran.

Berdasarkan hasil dari Uji t pada taraf signifikan 5\% adalah 2,148 $>2,00172$ atau $t_{\text {hitung }}>t_{\text {tabel }}$. Hal ini menunjukkan bahwa hipotesis $\left(\mathrm{H}_{0}\right)$ penelitian yang berbunyi "Tidak terdapat perbedaan kemampuan pemahaman konsep matematis yang belajar menggunakan model pembelajaran kooperatif tipe Team Assisted Individualization (TAI) dengan siswa yang belajar menggunakan model pembelajaran langsung" di tolak. Sehingga hasil pengujian hipotesis menunjukkan bahwa terdapat perbedaan kemampuan pemahaman konsep matematis yang belajar menggunakan model pembelajaran kooperatif tipe Team Assisted Individualization (TAI) dengan siswa yang belajar menggunakan model pembelajaran langsung.

Perbedaan kemampuan pemahaman konsep matematis yang belajar menggunakan model pembelajaran kooperatif tipe Team Assisted Individualization (TAI) dengan siswa yang belajar menggunakan model pembelajaran langsung terlihat dari perbedaan rata - rata nilai posttest siswa kelas eksperimen dan kelas kontrol yaitu 71,97 dan 58,63. Hal ini dikarenakan model pembelajaran kooperatif tipe TAI memberikan bantuan dan pengalaman belajar yang disesuaikan dengan kebutuhan siswa. setiap siswa memiliki pemahaman yang berbeda. Hal ini pula yang mendukung rumusan masalah yang diajukan yaitu terdapat perbedaan kemampuan pemahaman konsep matematis antara siswa yang mengikuti model pembelajaran kooperatif tipe TAI dengan siswa yang mengikuti pembelajaran langsung.

Hal ini juga sejalan dengan hasil penelitian yang dilakukan oleh Imra Atul Husna, Rahmi, Rina Febriana berjudul "Pengaruh Penerapan Model Pembelajaran Kooperatif Tipe Team Assisted Individualization (TAI) Terhadap Pemahaman Konsep Matematis Siswa Kelas IX MTsN Lembah Gumanti". Hasil penelitiannya yaitu model pembelajaran kooperatif tipe TAI dapat meningkatkan aktivitas siswa, pemahaman konsep matematis siswa dengan menerapkan model kooperatif tipe TAI lebih baik daripada pemahaman konsep matematis siswa dengan menerapkan model konvensional (Imra Atul Husna, Rahmi \& Rina Febriana, 2014).

Berdasarkan pemaparan tersebut maka dapat disimpulkan bahwa terdapat perbedaan kemampuan pemahaman konsep matematis yang belajar menggunakan model pembelajaran kooperatif tipe Team Assisted Individualization (TAI) dengan siswa yang belajar menggunakan model pembelajaran langsung. 
Berdasarkan Anova Dua Arah, untuk baris (antar tingkat Pengetahuan Awal Matematika), harga $F_{\text {hitung }}>F_{\text {tabel }}$, yaitu 5,0054 $>4,02$. Untuk kolom (antara kedua kelas eksperimen dan kelas kontrol), harga $F_{\text {hitung }}>F_{\text {tabel }}$, yaitu 3,8604 $>3,17$. Hal ini menunjukkan bahwa hipotesis $\left(\mathrm{H}_{0}\right)$ penelitian yang berbunyi "Tidak terdapat perbedaan kemampuan pemahaman konsep matematis antara siswa dengan pengetahuan awal matematika tinggi, sedang, rendah" di tolak. sehingga hasil pengujian hipotesis menunjukkan bahwa terdapat pengaruh kemampuan pemahaman konsep matematis antara siswa pengetahuan awal matematika tinggi, sedang, rendah.

Perbedaan kemampuan pemahaman konsep matematis antara siswa dengan pengetahuan awal tinggi, sedang dan rendah dapat dilihat dari nilai rata-rata posttest yang diperoleh siswa, ratarata nilai posttest siswa berpengetahuan awal tinggi pada kelas eksperimen sebesar 90,625 sedangkan pada kelas kontrol sebesar 65,75, rata-rata nilai posttest siswa berpengetahuan awal sedang pada kelas eksperimen sebesar 66,23 sedangkan pada kelas kontrol sebesar 58,6, dan rata - rata nilai posttest siswa berpengetahuan awal rendah pada kelas eksperimen sebesar 61,6 sedangkan pada kelas kontrol sebesar 50,57. Rata-rata nilai posttest berdasarkanpengetahuan awal matematika siswa dapat dilihat pada lampiran.

Berdasarkan hasil posttest terlihat terdapat perbedaan kemampuan pemahaman konsep matematis antara siswa dengan pengetahuan awal matematika tinggi, sedang, rendah. Hal ini dikarenakan penerapan model pembelajaran kooperatif tipe TAI pada kelas eksperimen memberikan keuntungan bagi siswa berkemampuan rendah dan sedang karena dapat belajar dengan kecepatan yang sesuai dengan kemampuannya dan tidak memberikan kerugian pada siswa yang berkemamuan tinggi. Pada proses pembelajaran siswa berkemampuan rendah dan sedang juga diberikan perhatian dan bantuan sesuai kebutuhannya dalam menyelesaiakan masalah yang diberikan.

Untuk interaksi harga $F_{\text {hitung }}<F_{\text {tabel }}$, yaitu $0,589<3,17$, berdasarkan hasil analisis dengan uji anova menunjukkan hipotesis $\left(\mathrm{H}_{0}\right)$ yang berbunyi "Tidak terdapat pengaruh Interaksi antara model pembelajaran kooperatif tipe Team Assisted Individualization (TAI) dengan pengetahuan awal matematika terhadap kemampuan pemahaman konsep matematis siswa" di terima. Dengan demikian model pembelajaran kooperatif tipe TAI tidak dipengaruhi oleh pengetahuan awal matematika siswa (pengetahuan awal tinggi, pengetahuan awal sedang dan pengetahuan awal rendah) dan kemampuan pemahaman konsep matematis siswa yang memiliki pengetahuan awal tinggi, pengetahuan awal sedang dan pengetahuan awal rendah tidak dipengaruhi oleh model pembelajaran kooperatif tipe TAI.

\section{KESIMPULAN}

Berdasarkan hasil penelitian yang telah diujikan mendapatkan kesimpulan yaitu:

1. Terdapat perbedaan kemampuan pemahaman konsep matematis siswa yang belajar menggunakan model pembelajaran kooperatif tipe Team Assisted Individualization (TAI) dengan siswa yang belajar menggunakan model pembelajarn langsung.

2. Terdapat perbedaan kemampuan pemahaman konsep matematis antara siswa dengan pengetahuan awal matematika tinggi, sedang dan rendah.

3. Tidak terdapat interaksi antara model pembelajaran dengan pengetahuan awal terhadap pemahaman konsep matematis siswa.

Berdasarkan hasil penelitian dapat diketahui bahwa terdapat pengaruh penerapan model pembelajaran kooperatif tipe Team Assisted Individualization (TAI) terhadap kemampuan pemahaman konsep matematis antara siswa dan terdapat perbedaan kemampuan pemahaman konsep matematis antara siswa dengan pengetahuan awal matematika tinggi, sedang dan rendah. 
Terdapat perbedaan maka dapat disimpulkan bahwa terdapat Pengaruh Penerapan Model Pembelajaran Kooperatif Tipe Team Asissted Individualization (TAI)Terhadap Kemampuan Pemahaman Konsep Matematis Siswa Ditinjau dari Pengetahuan Awal Matematika Siswa Madrasah Tsanawiyah. Namun, tidak terdapat interaksi dari ketiga faktor.

\section{REFERENSI}

Darto danMas'ud Zein. (2017). Evaluasi Pembelajaran Matematika. Jawa Timur: Wade Group National Publishing.

Hendriana, Heris dan Utari Soemarmo. (2014). Penilaian Pembelajaran Matematika. Bandung: Refika Aditama.

Husna, Imra Atul Rahmi dan Rina Febriana. (2014). Pengaruh Model Pembelajaran Kooperatif Tipe Team Assisted Individualization (TAI) Terhadap Pemahaman Konsep Matematis Siswa Kelas IX MTsN Lembah Gumanti.Jurnal Wisuda ke 48 Mahasiswa Prodi Pendidikan Matematika, Vol.1, No. 1.

Istarani dan Muhammad Ridwan. (2014). 50 Tipe Pembelajaran Kooperatif. Medan: Media Persada.

Lestari, Karunia Eka dan Mokhammad Ridwan Yudhanegara. (2017). Penelitian Pendidikan Matematika. Bandung: PT Refika Aditama.

Putri,Sari Desiana dkk. (2014). Pengaruh Penerapan Model Pembelajaran Kooperatif Tipe Teams Assisted Individualization Terhadap Pemahaman Konsep Matematis Siswa Kelas XI IPA SMAN 16 Padang.Jurnal Pendidikan Matematika, , Vol.3, No. 3.

Risnawati. (2013) Keterampilan Belajar Matematika. Yogyakarta: Aswajaya Pressindo.

Tim MKPBM Jurusan Pendidikan Matematika. (2001). Strategi Pembelajaran Matematik Kontemporer (Bandung : JICA-Universitas Pendidikan Indonesia.

Wena, Made. (2011), Strategi Pembelajaran Inovatif Kontemparer Suatu Tinjauan Konseptual Operasional. Jakarta: PT. Bumi Aksara. 